Hans Magnus Enzensberger Traduções de Vinicius Dantas 
"no livro de leitura do colegial" foi publicado em Defesa dos lobos [Verteidigung der Wölfe, 1956], primeiro livro de Enzensberger. "o outro", "pé de vento", os três poemas de sombras, "trivial" e "carceri d'invenzione" pertencem a Escrita de cegos [Blindenschrift, 1962]. "uma depois da outra", "a alegria", "a merda" e "a força do hábito" apareceram todos na coletânea de esparsos Poemas 1955-1970 [Gedichte 1955-1970, 1971]. "O novo homem" "O que foi aí figuram em Quiosque [Kiosk, 1995]. "Formas eólicas" e "Música do futuro" pertencem os dois a Música do futuro [Zukunftsmusik, 1993].

Por fidelidade ao modernismo caixa baixa, ou teimosia mesmo, mantive as minúsculas com que os poemas eram publicados até o fim dos anos 1960, pois só foi tempos depois que Enzensberger retornou ao uso de maiúscula para os substantivos, como é corrente em alemão, e para a abertura das estrofes. Por minha conta, adotei a forma "Passarges" em "Formas eólicas" mesmo sem ter certeza do seu significado preciso: tomei-a como um tipo de duna ou algum fenômeno geomorfológico ligado à desintegração da areia, tal qual barcana. Siegfried Passarge (1866-1958) foi um importante geógrafo e geomorfologista alemão que estudou a África e o deserto do Kalahari e criou o conceito de "fisiologia da paisagem" - unidade dinâmica que se constitui pelo intercâmbio com a litosfera, hidrosfera, atmosfera e ação humana.

Essas traduções nunca poderiam ter sido levadas a cabo se não tivessem sido minuciosamente discutidas e discutidas com várias pessoas, às quais devo um agradecimento sublinhado. A Noemia Mandelbaum e a Roberto Schwarz, que leram inúmeras versões e não se cansaram de sugerir mudanças e lembrar nuanças; a Guido Antonio de Almeida, a Virgínia de Araújo Figueiredo e a Jorge de Almeida, cujas leituras de versões adiantadas me obrigaram a alguns acertos de última hora ou, então, a ter coragem de voltar às primeiras soluções.

Vinicius Dantas (1956) é poeta. Traduziu poemas de William Carlos Williams, Sylvia Plath e Paul Celan, entre outros. Organizou, com lumna Maria Simon, a antologia Poesia concreta (Abril, 1982). 


\section{no livro de leitura do colegial}

não leias odes, meu filho, lê os horários das partidas:

são mais exatos. abre os mapas dos mares,

antes que seja tarde. fica atento, não cantes.

o dia está chegando em que eles pregarão de novo

listas nas portas e marcarão o peito

dos que dizem não. aprende a não te fazer notar, aprende mais do que eu:

a mudar de bairro, de passaporte, de cara.

adestra-te na pequena traição,

a suja salvação de cada dia. úteis

são as encíclicas para acender o fogo,

os manifestos: para embrulhar manteiga e sal

para os indefesos. raiva e paciência são necessárias

para insuflar nos pulmões do poder

o fino pó da morte, moído

por aqueles que aprenderam muito,

que são exatos, e por ti. 